University of New Hampshire

University of New Hampshire Scholars' Repository

Faculty Publications

$1-1-2000$

\title{
Sensitivity of a high-elevation rocky mountain watershed to altered climate and $\mathrm{CO} 2$
}

Jill S. Baron

U.S. Geological Survey

Melannie D. Hartman

Colorado State University

L. E. Band

Richard B. Lammers

University of New Hampshire, Durham, richard.lammers@unh.edu

Follow this and additional works at: https://scholars.unh.edu/faculty_pubs

Comments

This is an article published by AGU in Water Resources Research in 2000, available online: https://dx.doi.org/10.1029/

1999WR900263

\section{Recommended Citation}

Baron, J.S., M.D. Hartman, L.E. Band and R.B. Lammers (2000) Sensitivity of a high-elevation Rocky Mountain watershed to altered climate and CO2, Water Resources Research, 36(1):89-99.

This Article is brought to you for free and open access by University of New Hampshire Scholars' Repository. It has been accepted for inclusion in Faculty Publications by an authorized administrator of University of New Hampshire Scholars' Repository. For more information, please contact Scholarly.Communication@unh.edu. 


\title{
Sensitivity of a high-elevation Rocky Mountain watershed to altered climate and $\mathrm{CO}_{2}$
}

\author{
Jill S. Baron, ${ }^{1,2}$ Melannie D. Hartman, ${ }^{2}$ L. E. Band, ${ }^{3}$ and R. B. Lammers ${ }^{4}$
}

\begin{abstract}
We explored the hydrologic and ecological responses of a headwater mountain catchment, Loch Vale watershed, to climate change and doubling of atmospheric $\mathrm{CO}_{2}$ scenarios using the Regional Hydro-Ecological Simulation System (RHESSys). A slight $\left(2^{\circ} \mathrm{C}\right)$ cooling, comparable to conditions observed over the past 40 years, led to greater snowpack and slightly less runoff, evaporation, transpiration, and plant productivity. An increase of $2^{\circ} \mathrm{C}$ yielded the opposite response, but model output for an increase of $4^{\circ} \mathrm{C}$ showed dramatic changes in timing of hydrologic responses. The snowpack was reduced by $50 \%$, and runoff and soil water increased and occurred $4-5$ weeks earlier with $4^{\circ} \mathrm{C}$ warming. Alpine tundra photosynthetic rates responded more to warmer and wetter conditions than subalpine forest, but subalpine forest showed a greater response to doubling of atmospheric $\mathrm{CO}_{2}$ than tundra. Even though water use efficiency increased with the double $\mathrm{CO}_{2}$ scenario, this had little effect on basin-wide runoff because the catchment is largely unvegetated. Changes in winter and spring climate conditions were more important to hydrologic and vegetation dynamics than changes that occurred during summer.
\end{abstract}

\section{Introduction}

Water issues are prominent in the South Platte River basin of Colorado. This is a region with decades-long conflicts over water allocation between upstream federally owned lands with in-stream flow requirements, expanding urban populations, traditional agricultural irrigation uses, and downstream (Nebraska) endangered species concerns [Eisel and Aiken, 1997] (http://www.den.doi.gov/wwprac/). An underlying assumption to resolving these conflicting needs is that headwater source basins will continue to provide water from precipitation at least in quantities recorded in the past. This is not the scenario portrayed by some hydrologists who have conducted climate change effects modeling experiments. Rango and van Katwijk [1990] simulated snowmelt runoff scenarios for two Rocky Mountain basins. They found that a $3^{\circ} \mathrm{C}$ warming, with or without a $10 \%$ change in precipitation, could lead to a $20-40 \%$ decrease in runoff in the months where water demand is at its peak. They concluded that climate change would widen the gap between water supply and water demand as well as causing existing water storage and distribution systems to be ineffective [Rango and van Katwijk, 1990]. Similar conclusions were obtained using both snowmelt runoff models [Nash and Gleick, 1991; Revelle and Waggoner, 1983] and models that incorporated ecological processes such as evapotranspiration [Running and Nemani, 1991].

Increasing $\mathrm{CO}_{2}$ and other greenhouse gas concentrations

${ }^{1}$ U.S. Geological Survey, Fort Collins, Colorado.

${ }^{2}$ Natural Resource Ecology Laboratory, Colorado State University, Fort Collins.

${ }^{3}$ Department of Geography, University of North Carolina at Chapel Hill.

${ }^{4}$ Complex Systems Research Center, University of New Hampshire, Durham.

Copyright 2000 by the American Geophysical Union.

Paper number 1999WR900263.

0043-1397/00/1999WR900263\$09.00 are projected to warm air temperatures globally [Hansen et al., 1998; Watson et al., 1996]. In the mountainous regions of the western United States, general circulation model (GCM) projections suggest increases of $2.0^{\circ}-3.0^{\circ} \mathrm{C}$ in both minimum and maximum temperatures and slight increases in precipitation amounts, primarily during the winter months over the next 50 years (Hadley Centre's climate change experiments, http://ipcc-ddc.cru.uea.ac. uk/cru_data/datadownload/download_index.html (hereinafter Hadley Centre, 1998)). However, there will be additional regional variability in climate brought about by weather patterns, topography, vegetation, and land use [Cotton and Pielke, 1995]. Along the Colorado Front Range where the Great Plains adjoin the Rocky Mountains, for example, climate, discharge, and seedling development records show evidence that climate has cooled between $0.5^{\circ}$ and $1.0^{\circ} \mathrm{C}$ over the past $20-40$ years [Stohlgren et al., 1998; Williams et al., 1996a]. Mesoscale atmospheric simulations suggest mechanisms by which Front Range climate could behave differently than global projections [Chase et al., 1999; Stohlgren et al., 1998; Copeland et al., 1996]. These include decreased sensible heat fluxes and increased latent heat fluxes from the land surface of irrigated lands east of the Rockies, contributing to increased precipitation and cloud cover in the mountains [Chase et al., 1999; Stohlgren et al., 1998].

Hydrologic processes respond to changes in temperature and precipitation directly through the influence of snow accumulation and the timing and amount of runoff. Hydrologic processes also respond to changes in plant transpiration that are, in turn, influenced by physiological responses to increased atmospheric $\mathrm{CO}_{2}$ concentrations [Schlesinger, 1997]. This occurs because $\mathrm{CO}_{2}$ used in photosynthesis diffuses from the atmosphere into plant leaves through stomates. The stomatal aperture is one factor that determines the rate of photosynthesis, but when the stomates are open to allow $\mathrm{CO}_{2}$ to diffuse inward, $\mathrm{H}_{2} \mathrm{O}$ diffuses outward through the process of transpiration. The loss of water relative to photosynthesis is expressed as water-use efficiency (WUE). Water-use efficiency is higher at lower stomatal conductance (i.e., less water is transpired). 
Because elevated atmospheric $\mathrm{CO}_{2}$ allows the same rate of photosynthesis to occur at lower stomatal conductance, WUE should increase under conditions of increased greenhouse gases [Schlesinger, 1997]. Simulations of $\mathrm{CO}_{2}$-enhanced tree growth for basins in Ontario suggested that increased WUE offset enhanced water losses that were expected from higher temperatures and vapor pressure deficits [Band et al., 1996].

At the highest elevations of the Rocky Mountains, 60-85\% of annual precipitation occurs as snow [Baron, 1992; Barry, 1973]. Cold snowpacks accumulate beginning in October of each water year and only begin to melt when temperatures and solar radiation exceed a threshold each spring sometime between April and June [Cline, 1997]. The amount of moisture contained in the snowpack and the timing of snowmelt have important ecological, biogeochemical, and economic implications. Meadow and tundra vegetation communities and productivity are directly tied to soil moisture and number of snowfree days [Webber and May, 1977; Walker et al., 1994]. Stream and lake water quality are defined by snowmelt that flushes pollutants from the snowpack and nutrients and metals from soils [Baron, 1991; Denning et al., 1991; Campbell et al., 1995]. Because snowmelt is the major water supply source for agriculture and urban use in the western United States, it is important to understand implications of change in snow supply [Rango and van Katwijk, 1990]. A recent assessment in California found water to be the single most important economic resource of the Sierra Nevada [Sierra Business Council, 1996].

Loch Vale watershed is a typical Rocky Mountain basin at the headwaters of the South Platte River basin. We used the Regional Hydro-Ecological Simulation System (RHESSys) to conduct sensitivity analyses of hydrologic processes in Loch Vale watershed to climate change scenarios to address two questions: (1) How and (2) why do hydrologic discharge patterns and quantities change in response to climate change?

Explicit GCM scenarios are not used for this sensitivity analysis for two important reasons: GCMs provide (1) idealized scenarios at (2) a very large scale. While their ability to depict climate at global scale is rapidly improving, they cannot resolve important topographic and vegetation patterns of mountainous areas sufficiently to portray climate futures of mountains [Barry, 1994]. Mesoscale simulations, particularly for mountainous terrain, have shown these two parameters are important drivers of regional climate [Pielke et al., 1994; Giorgi et al., 1994]. Nested mesoscale models driven by GCM boundary conditions improve the spatial resolution but contribute their own model uncertainties, making them perhaps better localized climate scenarios than GCM output but scenarios with predictive uncertainties, nonetheless [Pielke et al., 1994; Giorgi et al., 1994]. We think it far sounder to conduct analyses of possible climate directions in order to allow assessment of the sensitivity of hydrologic and ecological processes to change. Because GCM results project warming with potentially greater precipitation, while existing records and regional models suggest localized recent cooling, we applied a suite of directional climate changes. The effects of doubling atmospheric $\mathrm{CO}_{2}$ on tundra and forest WUE and photosynthesis are also considered.

\section{Study Area}

Loch Vale watershed (LVWS) is a 7- $\mathrm{km}^{2}$ instrumented catchment east of the Continental Divide in Rocky Mountain National Park. It has been the focus of long-term ecological research and monitoring since 1983 [Baron, 1992]. LVWS ranges from 3000 to $4000 \mathrm{~m}$ and is largely unvegetated. It includes $82 \%$ rock and talus, $11 \%$ alpine tundra, $5 \%$ oldgrowth spruce-fir forest, and $2 \%$ open water and wetlands. In Rocky Mountain National Park and throughout the southern Rockies, more than one third of the landscape is above tree line, and greater than half of that is primarily rock and talus. Conditions in LVWS are typical of much of the headwater basins for the Platte, Colorado, Arkansas, and Rio Grande Rivers.

\section{Methods and Data Layers}

\subsection{Methods}

Simulations were made with the RHESSys model that is described in detail by Band [1993] and Band et al. 1993, 1996]. Further refinements for Loch Vale watershed are described by Hartman et al. [1999]. RHESSys is a data and simulation system that uses geographical information system techniques to transform spatial data into a landform description and a set of algorithms from process models that simulate water and carbon flux through watersheds [Band, 1993]. The process models are FOREST-BGC [Running and Coughlan, 1988; Hunt et al., 1996] and TOPMODEL [Beven and Kirkby, 1979; Band, 1993]. FOREST-BGC is a stand-level model of forest carbon budgets that has been parameterized for use in both forested and grassland systems [Running and Coughlan, 1988; Hunt et al., 1996]. We have further refined it for tundra to address the issue of soil freezing and wind redistribution [Hartman et al., 1999], processes identified as important in an early application of FOREST-BGC by Cairns [1994]. RHESSys uses the TOPMODEL-derived topographic similarity index (TSI), or wetness index, to simulate the potential base flow, runoff, and soil water distribution of any location in the watershed. Hartman et al. [1999] also used TSI to model snow redistribution. The TSI is computed as $\ln (A / \tan \beta)$, where $A$ is the upslope contributing area drained per unit contour and $\beta$ is the local slope [Beven and Kirkby, 1979]. RHESSys has been used to address regional-scale water and carbon budgets, climate change scenarios, forest and range productivity, nitrogen leaching, and responses to land use change in different regions of North America [Running and Coughlan, 1988; Band et al., 1993, 1996; Running and Nemani, 1991; Creed et al., 1996; Baron et al., 1998].

An important feature of RHESSys is the distributed approach to ecosystem process computations that allows the spatial interactions of water storage and flux processes to be represented on a landscape level [Lammers et al., 1997]. The distributed framework is based on a hydrologically defined terrain partition where each terrain object (valley sides) is separately parameterized and simulated. For these runs, LVWS was partitioned into 25 hydrologically independent valley sides, each of which was further partitioned into $200 \mathrm{~m}$ elevation bands [Lammers et al., 1997; Hartman et al., 1999]. Climate was extrapolated from the Loch Vale meteorological station at $\mathbf{3 1 6 0} \mathrm{m}$ based on the average elevation of the bands using a mountain weather-generator model [Running et al., 1987]. Each elevation band had one or more TSI intervals that are not spatially explicit but represent the proportions of a band with similar potential to become saturated with water [Band et al., 1993]. Model results for this paper were aggregated to the watershed scale.

Four years of observed LVWS climate (1991-1994) were altered in the following way for climate change scenarios: (1) 
For annual (year long) climate change, temperature and precipitation alterations were applied throughout the year: Air temperature was altered by adding $-2^{\circ} \mathrm{C},+2^{\circ} \mathrm{C}$, or $+4^{\circ} \mathrm{C}$ to daily minimum and maximum air temperatures. Precipitation was altered by increasing or decreasing daily precipitation $\pm 10 \%$ so that annual precipitation was also changed by $\pm 10 \%$. (2) For seasonal climate change, temperature alterations were the same as above, only within the season being altered. Precipitation was changed by an equal percentage each day within the season of interest. Annual and seasonal climate change scenarios were run for all combinations of temperature and precipitation amounts and for current as well as doubled $\mathrm{CO}_{2}$ levels. The $0^{\circ} \mathrm{C}, 0 \%$ precipitation change, and current $\mathrm{CO}_{2}$ run is the control run. Seasons in Loch Vale were defined by Baron and Bricker [1987]: Winter is October 1 to April 14 when precipitation is snow and discharge is low; spring is snowmelt and the rising limb of the hydrograph from April 15 to July 14; and summer represents the descending limb of the hydrograph from July 15 to September 30 . The model was run for 4 years, 1991-1994, which spanned a range of dry and wet years. The years 1991 and 1992 were used for model tuning, and results are shown for 1993 and 1994, the two validation years.

Plant responses to elevated $\mathrm{CO}_{2}$ were simulated by adjusting the canopy and mesophyll conductance in the equations that calculate canopy gross photosynthesis [after Lohammer et al., 1980]:

$$
\mathrm{GPSN}=\frac{\Delta \mathrm{CO}_{2} \mathrm{cg}_{c} g_{m}}{g_{c}+g_{m}},
$$

where $\Delta \mathrm{CO}_{2}$ is the $\mathrm{CO}_{2}$ diffusion gradient from leaf to air, $c$ is a $\mathrm{CO}_{2} / \mathrm{H}_{2} \mathrm{O}$ diffusion correction, $g_{c}$ is the canopy conductance, and $g_{m}$ is the mesophyll conductance. The physiological response of stomatal conductance to doubling of ambient $\mathrm{CO}_{2}$ concentrations was approximated by decreasing the maximum canopy conductance by $30 \%$ and increasing the mesophyll conductance by $30 \%$ [Cure and Acock, 1986]. This is the same approach followed by Band et al. [1996] and Running and Nemani [1991]. The Penman-Monteith equation used to calculate transpiration rates also includes the canopy conductance parameter $g_{c}$ [Monteith, 1965].

\subsection{Data Layers}

The 30-m resolution raster files were developed for elevation, biome classification, soil rooting depth, leaf area index (LAI), saturated hydraulic conductivity, and a distributed wind speed field (refer to Hartman et al. [1999] for detailed descriptions). Digital elevation and vegetation maps were provided by Rocky Mountain National Park; land cover, LAI, soil rooting depth, slope, aspect, TSI, and wind speed field map layers were derived from them. Vegetated areas were stratified into alpine tundra above $3350 \mathrm{~m}$ and coniferous forest below $3350 \mathrm{~m}$ for simplicity. Biome-specific parameters were used for evapotranspiration (ET) and photosynthesis calculations. Saturated hydraulic conductivity was derived from a detailed digitized soils map from Baron [1992]. Bedrock surfaces were assigned very small values for LAI, soil rooting depth, and hydraulic conductivity.

\section{Results}

The 1993 and 1994 control runs $\left(0^{\circ} \mathrm{C}, 0 \%\right.$ precipitation change, and current $\mathrm{CO}_{2}$ ) are identical to those of Hartman et al. [1999]. Simulated total annual outflow was within $8 \%$ of measured values for these two years, which were validation years (in other words, data not used to parameterize model runs) for the model development described by Hartman et al. [1999]. Analysis of the discrepancy, however slight (8\% is not a large difference), suggests undermeasurement of actual flows in addition to some amount of model error. It is also probably within the range of precipitation uncertainty that accompanies extrapolation of climate in steep topography from one meteorological station. Simulated evaporation, transpiration, and sublimation were also in agreement with previously reported estimates of these water loss terms from Baron and Denning [1992].

An independent measure of model output was made by comparing model-generated snow-covered area with panchromatic orthoimages of Loch Vale digitized from 1:12,000 aerial photographs. The snow classification techniques are described in detail by Hartman et al. [1999]. Digital images available for April 22, May 7, and May 21 of 1994 showed good agreement between simulated and observed spatial distribution of snow, except in areas where extreme wind scouring of tundra was not captured by the model.

\subsection{Responses to Temperature Change}

There was a nearly linear response to the year-long temperature change in the summaries for transpiration and evaporation (Table 1). Evaporation increased $51 \%$ with a year-long $4^{\circ} \mathrm{C}$ warming and decreased by $23 \%$ with year-long $2^{\circ} \mathrm{C}$ cooling. Photosynthesis, discharge, and sublimation showed a more complex pattern of response, although rates of photosynthesis, transpiration, evaporation, and discharge all increased with increasing temperatures (Table 1 and annual graphs of Figure 1). SWE changed dramatically with warming and cooling, although the responses to temperature were not linear. Transpiration increased by only $13 \mathrm{~mm}$ over the $6^{\circ} \mathrm{C}$ temperature range, but this was a large percentage change. The small total amount of increase reflects the lack of vegetative cover in LVWS. Discharge responded little, both in percent and absolute change, to temperature alteration.

Temperature adjustments made to individual seasons indicate that increases or decreases to summer temperatures had the least effect on total annual water and carbon fluxes compared to changes during other seasons on water losses and photosynthesis (Figure 1 and Table 1). Winter and spring temperature changes made a greater difference to these processes, with photosynthesis rates responding most to temperature changes during spring (mid-April to mid-July) and sublimation and discharge responding more to temperature variability during the winter (October to mid-April). In all scenarios, there was some slight amount of photosynthesis as early as March on warm days; this is because the warmth on dark needles and unfrozen soils allows water transport to occur, even with a snowpack covering the ground ( $R$. Boyce, personal communication, 1998).

Year-long temperature adjustments influenced the timing of ecological responses (Figure 2). A $2^{\circ} \mathrm{C}$ cooling pushed the onset of photosynthesis back by only one day, from March 22 to March 23, 1993, and April 16 to April 17, 1994, while warming by $4^{\circ} \mathrm{C}$ allowed growth to begin 3 days earlier (Figure 2). Transpiration responded similarly, since transpiration occurs when plants are photosynthetically active (Figure 2). Warmer temperatures caused somewhat higher photosynthesis and transpiration rates throughout the growing season, but the biggest responses to temperature occurred in the spring from April 20 to May 30, 1993, and from May 4 to June 1, 1994. 
Table 1. RHESSys Model Output of Ecological and Hydrologic Parameters, Showing Sensitivity to Changes in Annual and Seasonal Temperature and Precipitation

\begin{tabular}{|c|c|c|c|c|c|c|c|}
\hline & \multirow{2}{*}{$\begin{array}{c}\text { Control, } \\
\mathrm{mm}\end{array}$} & \multicolumn{3}{|c|}{$\begin{array}{c}\text { Change in } \\
\text { Temperature, \% }\end{array}$} & \multicolumn{2}{|c|}{$\begin{array}{c}\text { Change in } \\
\text { Precipitation, \% }\end{array}$} & \multirow{2}{*}{$\begin{array}{c}\text { Double } \\
\mathrm{CO}_{2}\end{array}$} \\
\hline & & $-2^{\circ} \mathrm{C}$ & $+2^{\circ} \mathrm{C}$ & $+4^{\circ} \mathrm{C}$ & $-10 \%$ & $+10 \%$ & \\
\hline \multicolumn{8}{|c|}{ Year-Long Climate Change } \\
\hline Photosynthesis & 118 & -13 & +10 & +18 & -1 & 0 & +15 \\
\hline Transpiration & 27 & -17 & +16 & +31 & $\mathbf{0}$ & $\mathbf{0}$ & -33 \\
\hline Evaporation & 79 & -23 & +23 & +51 & 0 & +1 & 0 \\
\hline Discharge & 824 & -4 & +3 & +5 & -13 & +13 & -1 \\
\hline Sublimation & 323 & +7 & -12 & -24 & -4 & +4 & -4 \\
\hline Snow water equivalent & 940 & +44 & -27 & -51 & -19 & +20 & 0 \\
\hline Soil water deficit & 479 & +1 & -3 & -8 & 0 & -1 & 0 \\
\hline ET & 106 & -22 & +22 & +45 & 0 & 0 & -8 \\
\hline Total vapor & 429 & 0 & -4 & -7 & -3 & +3 & -4 \\
\hline $\begin{array}{l}\text { Sublimation (as percent } \\
\text { of total vapor loss) }\end{array}$ & 75 & 81 & 69 & 62 & 74 & 76 & 77 \\
\hline \multicolumn{8}{|c|}{ Winter Season Climate Change } \\
\hline Photosynthesis & 118 & -1 & +3 & +4 & 0 & +1 & \\
\hline Transpiration & 27 & -3 & +4 & +7 & 0 & 0 & \\
\hline Evaporation & 79 & -4 & +7 & +20 & +4 & -4 & \\
\hline Discharge & 824 & -1 & +3 & +5 & -13 & +13 & \\
\hline Sublimation & 323 & +4 & -9 & -18 & -7 & +7 & \\
\hline Snow water equivalent & 257 & +5 & -14 & -35 & -31 & +31 & \\
\hline Soil water deficit & 132 & 0 & 0 & -9 & 0 & -1 & \\
\hline \multicolumn{8}{|c|}{ Spring Season Climate Change } \\
\hline Photosynthesis & 118 & -7 & +6 & +9 & +1 & $\mathbf{0}$ & \\
\hline Transpiration & 27 & -7 & +8 & +15 & 0 & $\mathbf{0}$ & \\
\hline Evaporation & 79 & -14 & +12 & +22 & -6 & +1 & \\
\hline Discharge & 824 & -1 & +1 & +1 & -13 & +14 & \\
\hline Sublimation & 323 & +2 & -3 & -5 & -1 & 0 & \\
\hline Snow water equivalent & 257 & +20 & -14 & -22 & -7 & +7 & \\
\hline Soil water deficit & 132 & 0 & +1 & +3 & 0 & -1 & \\
\hline \multicolumn{8}{|c|}{ Summer Season Climate Change } \\
\hline Photosynthesis & 118 & -4 & +2 & +3 & +1 & -1 & \\
\hline Transpiration & 27 & -3 & +5 & +11 & 0 & 0 & \\
\hline Evaporation & 79 & -5 & +5 & +10 & -10 & +2 & \\
\hline Discharge & 824 & -1 & 0 & +1 & -14 & +14 & \\
\hline Sublimation & 323 & +1 & -1 & -1 & 0 & $\mathbf{0}$ & \\
\hline Snow water equivalent & 257 & +7 & -7 & -11 & -2 & +2 & \\
\hline Soil water deficit & 132 & -1 & 0 & 0 & +1 & -1 & \\
\hline
\end{tabular}

Values are annual totals averaged from the 2-year (1993-1994) simulation, except for snow water equivalent (SWE) and soil water deficit (SWD), which represent the mean daily average of these variables. The annual average measured precipitation for 1993-1994 was $1101 \mathrm{~mm}$. Percent differences are deviations away from the control run, where measured precipitation and temperature values were used. Photosynthesis rates are in $\mathrm{g} \mathrm{C} \mathrm{m}^{-2} \mathrm{yr}^{-1}$. Snow water equivalent and soil water deficit are annual totals in millimeters. Maximum SWE was $586 \mathrm{~mm}$, while maximum SWD was $193 \mathrm{~mm}$. All other units are $\mathrm{mm}$ $\mathrm{yr}^{-1}$. ET is evapotranspiration, and ET plus sublimation is total vapor.

The timing of hydrologic responses was sensitive to yearlong temperature adjustments (Figure 3). Evaporation became significant in the control runs on May 10, 1993. Cooler temperatures delayed the onset of evaporative losses by only 1 day, but warming by $4^{\circ} \mathrm{C}$ caused evaporation to become significant on March 10, 1993, a full 2 months earlier. This occurrence was repeated in 1994. Evaporation was not significant after October 9,1993 , in the control runs but continued an additional 3 weeks to October 30,1993 , with a $4^{\circ} \mathrm{C}$ warming. The pattern was not as apparent at the end of the summer in 1994.

Snow water equivalent (SWE) was reduced by warming and increased by cooling (Figure 3), but annual and seasonal summaries show that the changes were not linear (Table 1). Whereas snowmelt in the control runs began on May 8, 1993, and May 1, 1994, melt initiation occurred on May 17, 1993, and May 7,1994 , or about a week later, with a $2^{\circ} \mathrm{C}$ cooling. The $4^{\circ} \mathrm{C}$ warming scenario caused snowmelt to begin on April 11, 1993, and April 7, 1994, or 2-3 weeks earlier than control. There is a small permanent snowpack in Loch Vale with current conditions, but this snowpack disappeared with the $4^{\circ} \mathrm{C}$ scenario and nearly disappeared with the $2^{\circ} \mathrm{C}$ scenario. The responses to seasonal climate changes only in Table 1 explain more of the processes involved. Winter cooling had little effect on SWE, increasing the total SWE by only $5 \%$, while winter warming decreased total snowpack by $35 \%$. Spring cooling kept snow on the ground longer, while warming melted it off earlier.

Sublimation was greatest under conditions that favored the most extensive snow-covered area. Sublimation increased with decreasing temperature, and seasonally winter cooling resulted in the greatest annual increase in sublimation (Table 1). Sublimation comprised $62-81 \%$ of the total annual vapor loss (ET plus sublimation) with year-long temperature change. During the time period when all temperature scenarios show that snow is in the basin, sublimation responses were similar among the 

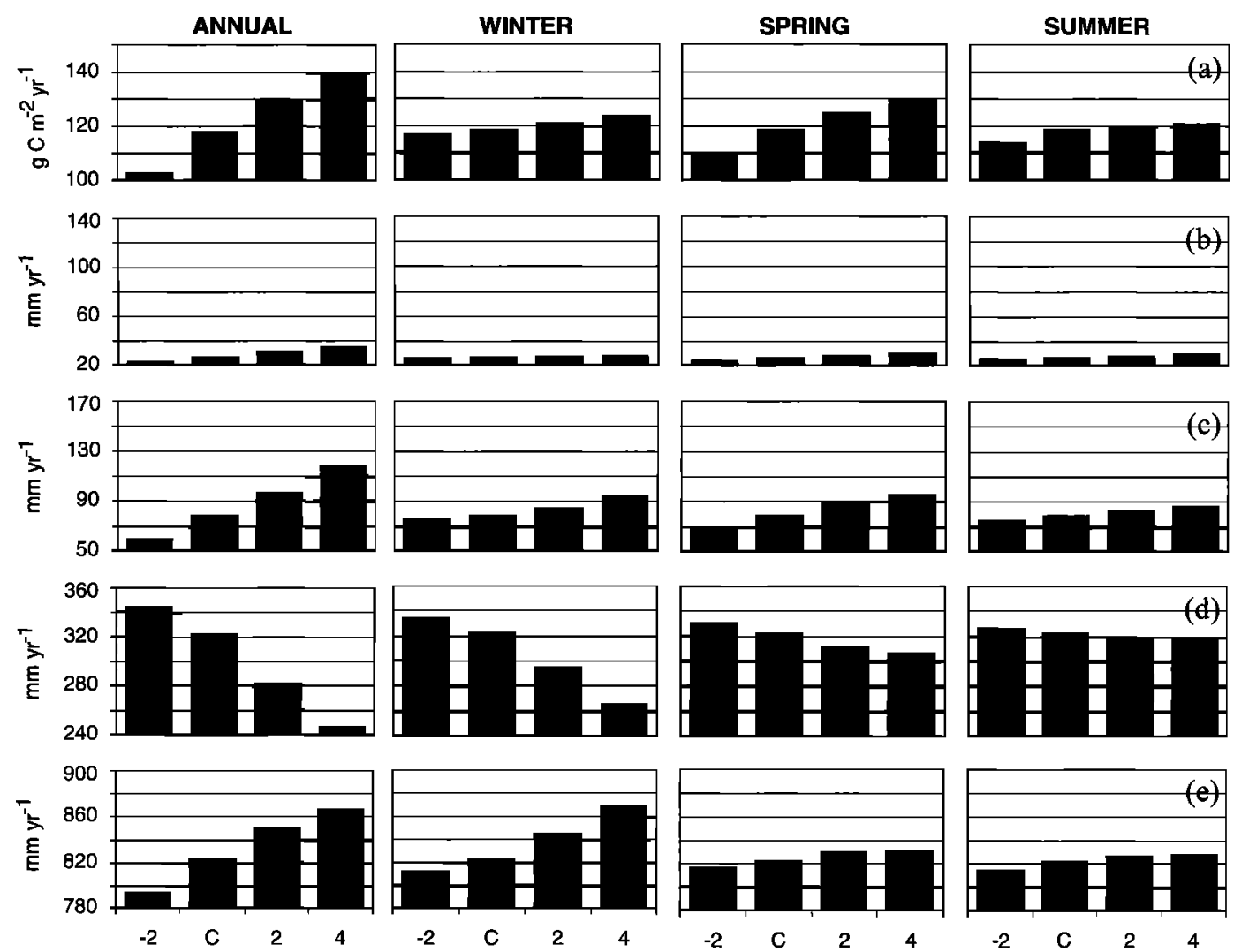

Figure 1. Regional hydro-ecological simulation system (RHESSys) model output for year-long and seasonal

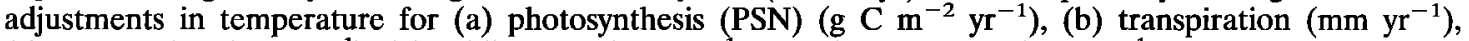
(c) evaporation $\left(\mathrm{mm} \mathrm{yr}^{-1}\right)$, (d) sublimation $\left(\mathrm{mm} \mathrm{yr}^{-1}\right)$, and (e) discharge $\left(\mathrm{mm} \mathrm{yr}^{-1}\right)$. The values represent annual totals (averages of 1993 and 1994 simulations) when temperatures were adjusted by $2^{\circ}$ or $4^{\circ}$ from control temperatures for the entire year (year long) or individual seasons (winter, October 1 to April 14; spring, April 15 to July 14; and summer, July 15 to September 30). Note that ordinate scales for the water loss terms are the same, although starting points differ.

different scenarios, differing only in magnitude (Figure 3 ). The difference in magnitude of total annual sublimation is large, however (Figure 1).

Soil water deficit measures "water equivalent" depth to the saturated zone in millimeters, and displays interesting dynamics related to temperature changes (Figure 3). Smaller values of the soil water deficit means there is greater soil moisture. Soils were dry through the winter in the $-2^{\circ} \mathrm{C}, 0^{\circ} \mathrm{C}$, and $+2^{\circ} \mathrm{C}$ scenarios, differing mostly in when snowmelt began to cause the soil moisture to increase. In 1993 these were May 26, May
13, and April 26 and May 9, April 19, and April 17 for 1994 for the $-2^{\circ} \mathrm{C}, 0^{\circ} \mathrm{C}$, and $+2^{\circ} \mathrm{C}$ scenarios, respectively. Once snowmelt began, soils wetted up rapidly. Soil wetting was different under a $+4^{\circ} \mathrm{C}$ scenario. In both years, soils began to gain moisture early in the spring, March 24, 1993, and March 5, 1994, and gradually reduced the deficit through the spring. Soils dried to a greater extent during the summer growing season in this warming scenario, losing about $20 \mathrm{~mm}$ more than the $-2^{\circ} \mathrm{C}$ scenario.

Warming and cooling scenarios changed total annual dis-

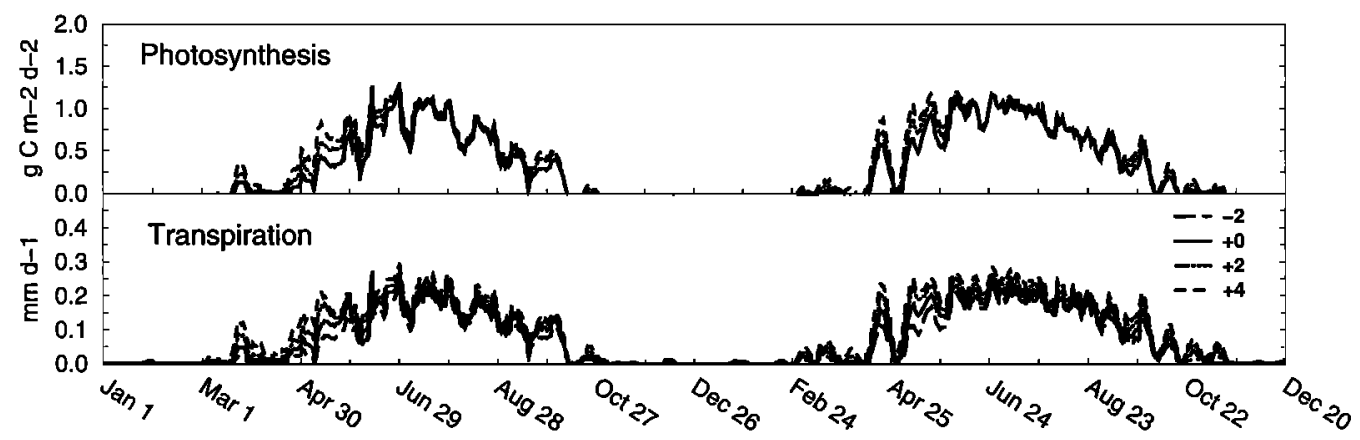

Figure 2. Daily simulated ecological responses to year-long temperature changes from January 1, 1993, to December 20 , 1994. Shown are watershed-scale photosynthesis $\left(\mathrm{g} \mathrm{C} \mathrm{m}^{-2} \mathrm{~d}^{-1}\right)$ and transpiration $\left(\mathrm{mm} \mathrm{d}^{-1}\right)$. 


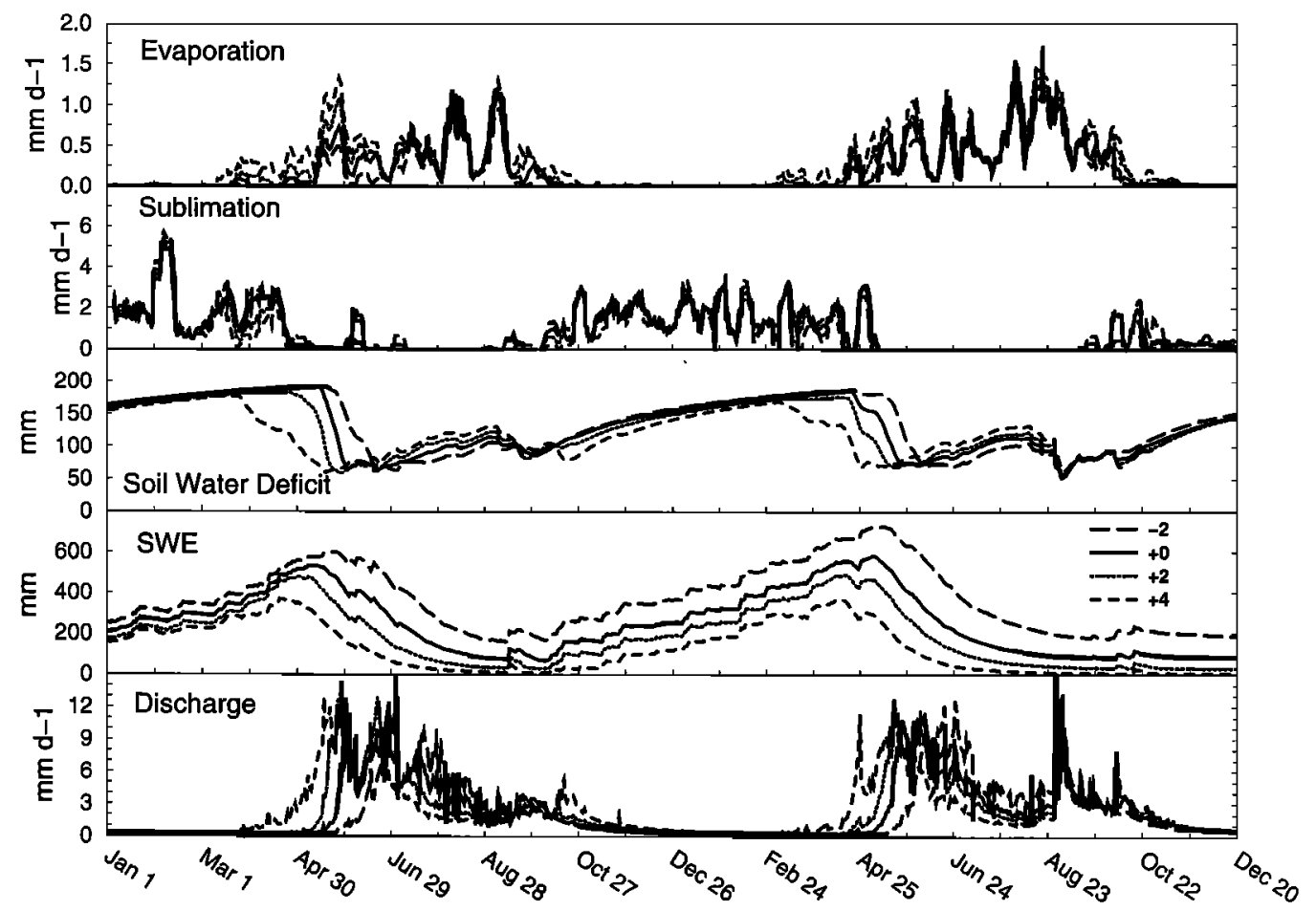

Figure 3. Daily simulated hydrologic responses to year-long temperature changes. Evaporation, sublimation, and discharge are in $\mathrm{mm} \mathrm{d}^{-1}$. Soil water deficit and snow water equivalent (SWE) are in millimeters.

charge slightly ( $+5 \%$ with warming and $-4 \%$ with cooling) but had a dramatic effect on the timing of discharge (Figure 3). Snowmelt-initiated streamflow began on May 11, 1993, and April 26, 1994, for the control runs, and as mentioned above, model output closely matched measured streamflow values. Warming by $+4^{\circ} \mathrm{C}$ initiated stream discharge a full 48 days earlier in 1993 but only 14 days earlier in 1994. Cooling delayed the rising limb of the hydrograph by 30 days in 1993 and 14 days in 1994. While the warm temperature scenario hydrograph did not show a more pronounced peak than the others, summer flows were lower than the other scenarios, and they were less responsive to summer storm events.

\subsection{Responses to Precipitation Change}

Precipitation varied from $1191 \mathrm{~mm} \mathrm{yr}^{-1}$ in the control runs to $1072 \mathrm{~mm} \mathrm{yr}^{-1}$ with $10 \%$ less precipitation and $1310 \mathrm{~mm} \mathrm{yr}^{-1}$ with $10 \%$ greater precipitation. Discharge, sublimation, and SWE were the only parameters to respond to annual and seasonal changes in precipitation, and those changes were linear (Table 1). When broken down by season, photosynthesis and transpiration again did not respond, but evaporation showed seasonal responses (Table 1). Rates of evaporation increased slightly (4\%) with lower winter precipitation, because of more exposure of bare soil and less snow cover. Similarly, winter evaporation decreased by $4 \%$ with increased winter precipitation. Decreases in spring or summer precipitation amounts led to decreases in evaporation rates $(-6 \%$ and $-10 \%$ for spring and summer, respectively), while increased precipitation for these seasons led to much smaller increases in evaporation (+1-2\% for both seasons). Soil water deficit was much less responsive to year-long precipitation change than to changes in temperature.

\subsection{Responses to Doubling of $\mathrm{CO}_{2}$}

Under the double $\mathrm{CO}_{2}$ with control climate scenario, rates of photosynthesis increased by $15 \%$, and rates of transpiration decreased by $31 \%$ over the control runs $\left(0^{\circ} \mathrm{C}, 0 \%\right.$ precipitation, and current $\mathrm{CO}_{2}$ ) (Table 1). The increase in photosynthesis occurred under all temperature and precipitation scenarios (Figure 4). The decrease in transpiration was $17 \mathrm{~mm}$ and matched an increase in stream discharge, so the effect of doubling $\mathrm{CO}_{2}$ was $1 \%$, an insignificant change in discharge. Note that the increased carbon availability from doubling $\mathrm{CO}_{2}$ caused nearly as great a percent increase in photosynthesis under the control climate as increasing the temperature by $4^{\circ} \mathrm{C}$ alone. Carbon availability had no effect on strictly hydrologic variables such as evaporation and sublimation.

Tundra and forest displayed different responses to climate changes and $\mathrm{CO}_{2}$ (Table 2). Tundra increased productivity by $6 \%$, but forest increased productivity $17 \%$ over the control runs. This may be due to the longer growing season at lower elevations. Forest productivity was more responsive than tundra to alterations in temperature, whereas tundra productivity was sensitive to changes in precipitation (Table 2). While individual tundra or forest species may respond more or less favorably to climate change, RHESSys is a stand-level model; issues of species response cannot be resolved.

\subsection{Extreme Responses to Climate Variability}

We looked at which of the year-long and seasonal climate change scenarios caused the greatest or least response in basinwide ecological and hydrologic variables. Extreme events are important because they are often the impetus for ecological change [Holling, 1996] and hydrologic events [Grassl, 1994]. The extreme minimum and maximum values shown in Table 3 


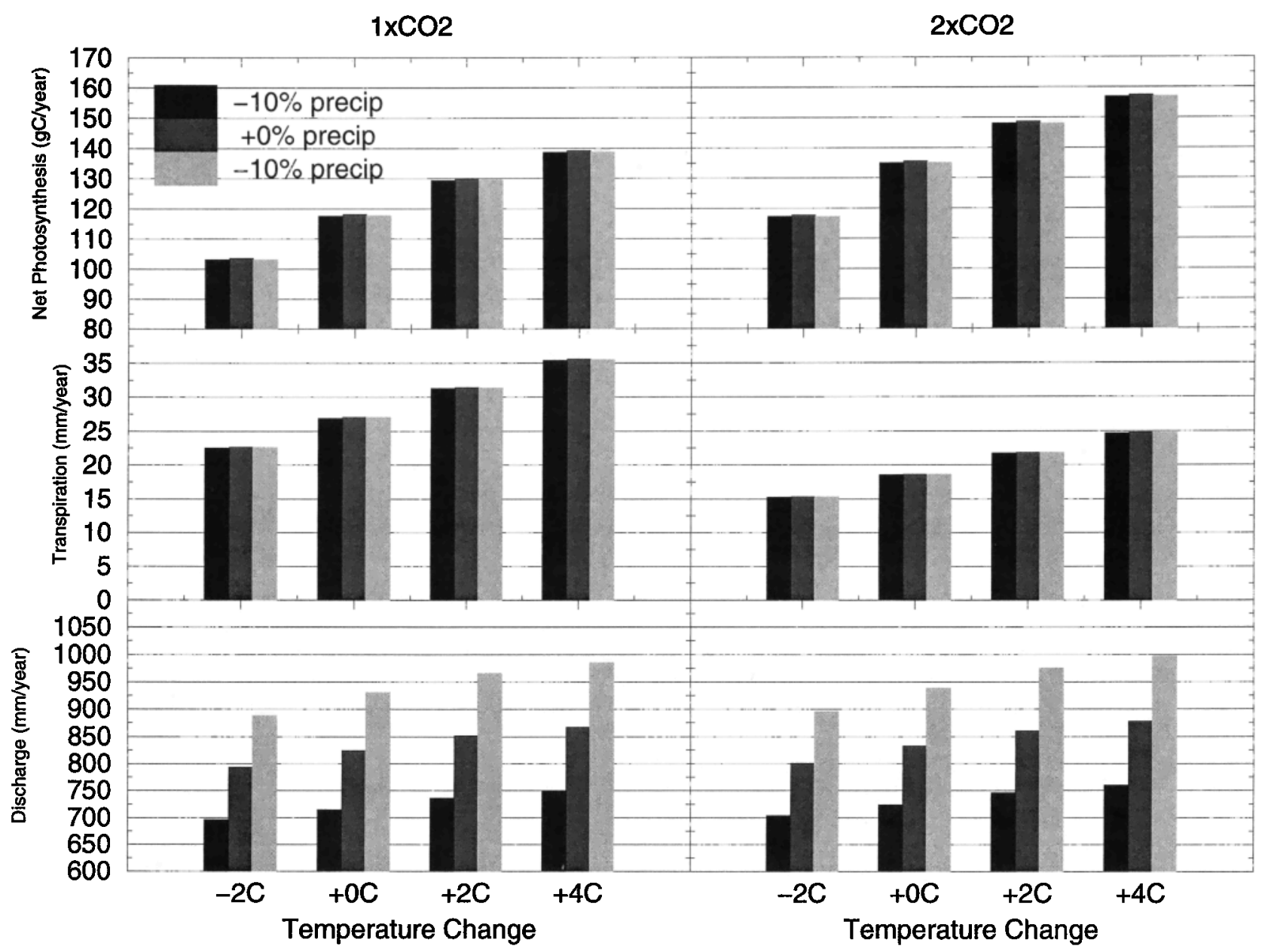

Figure 4. Comparison of responses of annual total net photosynthesis, transpiration, and discharge to year-long temperature change ( $x$ axis), precipitation (shaded bars), and doubling of $\mathrm{CO}_{2}$ (right set of graphs). Figure 4 clearly shows responses of photosynthesis and transpiration to temperature and $\mathrm{CO}_{2}$, while discharge is most responsive to precipitation and is only slightly responsive to temperature. The control run is $0^{\circ} \mathrm{C}, 0 \%$ precipitation, and $1 \times \mathrm{CO}_{2}$.

Table 2. Changes in Rates of Photosynthesis by Vegetation Type: Tundra or Subalpine Forest

\begin{tabular}{lcc}
\hline & Tundra & Forest \\
\hline Control & $17 \mathrm{~g} \mathrm{C} \mathrm{m}^{-2} \mathrm{yr}^{-1}$ & $679 \mathrm{~g} \mathrm{C} \mathrm{m}^{-2} \mathrm{yr}^{-1}$ \\
Year-long runs & $-8 \%$ & $-11 \%$ \\
$-2^{\circ} \mathrm{C}$ & $+8 \%$ & $+8 \%$ \\
$+2^{\circ} \mathrm{C}$ & $+9 \%$ & $+12 \%$ \\
$+4^{\circ} \mathrm{C}$ & $-8 \%$ & $0 \%$ \\
$-10 \%$ precipitation & $+5 \%$ & $-2 \%$ \\
$+10 \%$ precipitation & $+6 \%$ & $+17 \%$ \\
$2 \times \mathrm{CO}_{2}$ & & \\
Seasonal maximum runs & & \\
$\left(+4{ }^{\circ} \mathrm{C},+10 \%\right.$ precipitation, & & $+23 \%$ \\
$\left.2 \times \mathrm{CO}_{2}\right)$ & & $+23 \%$ \\
Winter & $+17 \%$ & $+16 \%$ \\
Spring & $+21 \%$ & \\
Summer & $+14 \%$ & \\
\hline
\end{tabular}

In the model runs, tundra areas cover $563430 \times 30 \mathrm{~m}$ grid cells; forest covers $103130 \times 30 \mathrm{~m}$ grid cells. Control values are $94 \mathrm{~g} \mathrm{C} \mathrm{m}^{-2}$ $\mathrm{yr}^{-1}$ for tundra and $700 \mathrm{~g} \mathrm{C} \mathrm{m}^{-2} \mathrm{yr}^{-1}$ for forest. Values are percentage change away from the year-long control runs.

${ }^{*}$ Increase of $4^{\circ} \mathrm{C}$ and $10 \%$ precipitation and doubling of $\mathrm{CO}_{2}$. (for comparison refer to Table 1) illustrate the important control of temperature over rates of photosynthesis, transpiration, evaporation, SWE, and outflow. The importance of temperature controls held for both year-long and seasonal climate change extremes. Annual sublimation, SWE, and outflow were further influenced by precipitation, and evaporation during the spring responded to changes in precipitation. Photosynthesis, transpiration, and outflow were influenced by doubling $\mathrm{CO}_{2}$; all other variables were insensitive.

Each variable's degree of sensitivity to climate change depended on the season in which climate variances occurred (Table 3). Basin-wide photosynthesis was greatest when temperatures were warmer throughout the year and were least when they were uniformly cooler. Evaporation was greatest with the warmest temperatures, while spring values depended on how much of the ground was snow-covered thus converting evaporative loss to sublimation instead of evaporation. The minimum values for sublimation occurred when the winters were warm and dry, more so than the scenario where the entire year was warmer and drier. SWE maxima were far more re- 
Table 3. Extreme Values From Year-Long and Seasonal Climate Change Scenarios

\begin{tabular}{|c|c|c|c|c|}
\hline \multirow[b]{2}{*}{ Parameter } & \multicolumn{2}{|c|}{ Minima } & \multicolumn{2}{|c|}{ Maxima } \\
\hline & $\begin{array}{c}\text { Year-Long } \\
\text { Climate Change }\end{array}$ & $\begin{array}{c}\text { Seasonal } \\
\text { Climate Change }\end{array}$ & $\begin{array}{c}\text { Year-Long } \\
\text { Climate Change }\end{array}$ & $\begin{array}{c}\text { Seasonal } \\
\text { Climate Change }\end{array}$ \\
\hline Photosynthesis & $103 \pm 10 \mathrm{p},-2 \mathrm{t}$ & 109 spring $+10 p,-2 t$ & $139 \pm 10 p,+4 t$ & 130 spring $-10 p,+4 t$ \\
\hline Photosynthesis, $2 \times \mathrm{CO}_{2}$ & $118 \pm 10 \mathrm{p},-2 \mathrm{t}$ & 125 spring $+10 p,-2 t$ & $157 \pm 10 \mathrm{p},+4 \mathrm{t}$ & 149 spring $-10 p,+4 t$ \\
\hline Transpiration & $23 \pm 10 p,-2 t$ & 21 spring $-10 \mathrm{p},-2 \mathrm{t}$ & $36 \pm 10 \mathrm{p},+4 \mathrm{t}$ & 31 spring $-10 \mathrm{p},+4 \mathrm{t}$ \\
\hline Transpiration, $2 \times \mathrm{CO}_{2}$ & $16 \pm 10 \mathrm{p},-2 \mathrm{t}$ & 17 spring at $\pm 10 \mathrm{p},-2 \mathrm{t}$ & $25 \pm 10 \mathrm{p},+4 \mathrm{t}$ & 22 spring $\pm 10 \mathrm{p},+4 \mathrm{t}$ \\
\hline Soil water deficit & $117+10 \mathrm{p},+4 \mathrm{t}$ & 116 winter $+10 \mathrm{p},+4 \mathrm{t}$ & $137-10 \mathrm{p},-2 \mathrm{t}$ & 133 spring $-10 \mathrm{p},+4 \mathrm{t}$ \\
\hline $\mathrm{SWD}, 2 \times \mathrm{CO}_{2}$ & $117+10 \mathrm{p},+4 \mathrm{t}$ & 116 winter $+10 \mathrm{p},+4 t$ & $137-10 \mathrm{p},-2 \mathrm{t}$ & 141 summer $-10 p,+4 p$ \\
\hline Evaporation & $60+10 p,-2 t$ & 65 spring $-10 \mathrm{p},-2 \mathrm{t}$ & $119 \pm 10 \mathrm{p},+4 \mathrm{t}$ & 99 spring $+10 \mathrm{p},+4 \mathrm{t}$ \\
\hline Evaporation, $2 \times \mathrm{CO}_{2}$ & $60+10 \mathrm{p},-2 \mathrm{t}$ & 65 spring $-10 \mathrm{p},-2 \mathrm{t}$ & $119 \pm 10 \mathrm{p},+4 \mathrm{t}$ & 99 spring $+10 \mathrm{p},+4 \mathrm{t}$ \\
\hline Sublimation & $236-10 \mathrm{p},+4 \mathrm{t}$ & 248 winter $-10 \mathrm{p},+4 \mathrm{t}$ & $360+10 \mathrm{p},-2 \mathrm{t}$ & 357 winter $+10 \mathrm{p},-2 \mathrm{t}$ \\
\hline Sublimation, $2 \times \mathrm{CO}_{2}$ & $236-10 \mathrm{p},+4 \mathrm{t}$ & 248 winter $-10 p,+4 t$ & $360+10 p,-2 t$ & 357 winter $+10 \mathrm{p},-2 \mathrm{t}$ \\
\hline SWE & $102-10 \mathrm{p},+4 \mathrm{t}$ & 116 winter $-10 \mathrm{p},+4 \mathrm{t}$ & $449+10 p,-2 t$ & 355 winter $+10 \mathrm{p},-2 \mathrm{t}$ \\
\hline SWE, $2 \times \mathrm{CO}_{2}$ & $102-10 \mathrm{p},+4 \mathrm{t}$ & 116 winter $-10 p,+4 t$ & $449+10 p,-2 t$ & 355 winter $+10 \mathrm{p},-2 \mathrm{t}$ \\
\hline Outflow & $697-10 \mathrm{p},-2 \mathrm{t}$ & 703 summer $-10 \mathrm{p},-2 \mathrm{t}$ & $986+10 \mathrm{p},+4 \mathrm{t}$ & 987 winter $+10 \mathrm{p},+4 \mathrm{t}$ \\
\hline Outflow, $2 \times \mathrm{CO}_{2}$ & $704-10 \mathrm{p},-2 \mathrm{t}$ & 711 summer $-10 \mathrm{p},-2 \mathrm{t}$ & $997+10 \mathrm{p},+4 \mathrm{t}$ & 996 winter $+10 \mathrm{p},+4 \mathrm{t}$ \\
\hline
\end{tabular}

Control values are found in Table 1 for comparison. Units for photosynthesis are $\mathrm{g} \mathrm{C} \mathrm{m}^{-2} \mathrm{yr}^{-1}$. Transpiration, evaporation, sublimation, and outflow are $\mathrm{mm} \mathrm{yr}^{-1}$. Soil water deficit (SWD) and SWE are average daily values in millimeters. Values are minima and maxima averaged from the 2-year (1993 and 1994) simulation. Climate scenarios included varying daily 1993 and 1994 precipitation by $\pm 10 \%(+10 p,-10 \mathrm{p})$ and 1993 and 1994 daily temperature by $-2^{\circ},+2^{\circ}$, and $+4^{\circ} \mathrm{C}(-2 t,+2 t$, and $+4 t)$. Refer to text for further explanation.

sponsive to cooler and wetter conditions throughout the year than they were to the same scenario during winter season only. Total annual outflow was only slightly responsive to whether or not climate varied through the year or seasonally.

Tundra and forest vegetation were more productive in all seasons under a warmer, wetter, double $\mathrm{CO}_{2}$ scenario (Table 2 ). Both vegetation types responded to changes in all seasons, but tundra responded greatest to springtime climate change. Forest photosynthesis rates increased by $23 \%$ when either winter or spring climate conditions became warmer and wetter. Changes in summer climate made the least difference in annual photosynthesis rates, although warmer, wetter, double $\mathrm{CO}_{2}$ conditions still caused an annual productivity increase of $14 \%$ for tundra and $16 \%$ for forest.

\section{Discussion}

\subsection{Ecological Responses}

The sensitivity simulations yield insight into controls on ecological and hydrologic processes as well as into the consequences of climate variability. Water is abundant at high elevations because of the seasonal snowpack. Other researchers have noted that high-elevation forests are limited by temperature, not water, and our results concur [Peet, 1989]. While the response of forest productivity to changes in precipitation was negligible, tundra showed a water limitation, decreasing productivity with a reduction in annual precipitation and increasing productivity with precipitation increase. Basin-wide photosynthesis showed a modest increase due to year-long warming, largely because so little of the watershed is vegetated. Spring warming accounts for half of the total annual increase in basinwide photosynthesis and transpiration because of the extended growing season. The forest has 7 times the productivity of tundra, and the lack of water stress allowed for a greater response to increased temperatures than areas above tree line.

Transpiration was insensitive to precipitation but highly responsive to temperature changes. Both photosynthesis and transpiration were highly responsive to doubled $\mathrm{CO}_{2}$. The results of warming and doubling $\mathrm{CO}_{2}$ were additive, so a warmer and carbon-rich environment increased plant growth by $30 \%$ (Figure 4).

\subsection{Hydrologic Responses}

Annual summaries shown in Table 1 suggested sufficient water was available such that ET was influenced by temperature alone, in contrast to drier climates where energy to evaporate water and plant demand exceed the available moisture [Sims, 1989]. Sublimation decreased with warming because of the resulting decreased volume and spatial extent of snow. Interestingly, there was a slight decrease in water lost via vaporization with warming when ET plus sublimation were considered. Since ET and sublimation incline or decline in opposite directions in response to temperature change, total vaporization remains within $7 \%$ of the control for all year-long temperature adjustments.

Sublimation, SWE, and soil water deficit were related to each other, and all these influenced discharge. Cool temperatures, particularly cooler springs, allowed for greater snow accumulation. Year-long cooling tied up water in the snowpack throughout the year at the expense of being released as discharge. Warming caused a nonlinear response in SWE; yearlong $4^{\circ} \mathrm{C}$ warming decreased average daily SWE by half, with strong decreases in peak accumulation. Winter snowmelt with both $2^{\circ} \mathrm{C}$ and $4^{\circ} \mathrm{C}$ warming delivered water to the streams and soils earlier in the year. Although total annual discharge and average daily soil moisture increased with warming, the earlier release of water from the snowpack and increased ET in spring and summer caused drier soil conditions and diminished discharge in late summer.

Examination of seasonal rates show that evaporation was indirectly influenced by precipitation. Lower-precipitation scenarios reduced snow-covered area, exposed soil, and increased total basin evaporation, while at the same time decreasing total basin sublimation and snow water equivalent. Increased precipitation produced the opposite effect. Spring precipitation scenarios were more complicated because the warming spring temperatures made for a less direct relation between precipitation and snowpack. Summer decreases in precipitation led to 
a direct decrease in evaporation under the control scenario for temperature, but decreased summer precipitation with warmer temperatures caused evaporation to decline only slightly.

Discharge displayed a complicated response to changes in precipitation and temperature that is partly explained by physical processes and partly by ecological processes. There was a direct flow response to precipitation, in that less precipitation caused less flow and more precipitation caused more flow. Warming with no change in precipitation led to slightly greater discharge (more snowmelt). Warming coupled with drying led to slightly less discharge because of greater plant transpiration.

The increased water-use efficiency that accompanied an increase in atmospheric $\mathrm{CO}_{2}$ can offset evaporation losses that increase with warming. For LVWS, double $\mathrm{CO}_{2}$ simulations show a constant $8 \mathrm{~mm} \mathrm{yr}^{-1}$ decrease in transpiration over the control for all year-long temperature adjustments. Given the linear increase in ET with temperature, we calculated $0.8^{\circ} \mathrm{C}$ warming is necessary before ET rates with doubled $\mathrm{CO}_{2}$ surpass current ET rates. The effect of WUE on ET rates may be even greater in a watershed with a larger extent of forest/plant cover. Biomass and vegetation boundaries are fixed inputs to RHESSys, so we were not able to explore this avenue further with simulations. In LVWS, where there is little vegetation to begin with, elevated $\mathrm{CO}_{2}$ and warming may help vegetation to expand and thus capture more of the water budget than at present. The longer growing season below tree line, and the greater response to warming combine to suggest that forests will expand at the expense of tundra in a warmer, wetter, and enriched $\mathrm{CO}_{2}$ world. Vegetation expansion and retraction has happened in Loch Vale through the Holocene in response to large-scale climatic change [Reasoner, 1996], and increased height and tree density of existing krummholz patches at tree line in recent decades illustrates the rapidity with which vegetation can respond to climatic changes [Baker and Weisberg, 1995; Graumlich, 1994].

The maximum and minimum output values (extreme runs) suggest that climate changes that occur during the winter and spring seasons are more important at controlling hydrologic dynamics than climate variability during the summer. This agrees with many other analyses of snowmelt-driven catchments, such as those of Rango and van Katwijk [1990], van Katwijk et al. [1993], Lettenmaier and Gan [1990], Dracup and Kendall [1990]. Sublimation, SWE, and outflow were most responsive to temperature changes that occurred at the beginning and end of the winter season. Under the warmest scenario, however, midwinter temperatures rose to the point where snow melt became dynamic and allowed water to melt into soils a full 4 to 5 weeks earlier than currently occurs. It appears a response threshold is crossed at warming above $+2^{\circ} \mathrm{C}$, most readily seen in Figure 4 for soil water deficit. With $+2^{\circ} \mathrm{C}$ warming the soil water deficit decreases slightly earlier than in control runs but generally follows the same pattern of wetting and drying. With $+4^{\circ} \mathrm{C}$, snow melts much earlier, and soils remain wet through much of the winter season.

While the changes in hydrologic processes in LVWS are dramatic, they are far less so than climate-warmed hydrologic response simulated for four California Sierra Nevada basins [Lettenmaier and Gan, 1990; Melack et al., 1997]. The warming in the California runs was sufficient to change a large proportion of precipitation from snow to rain, greatly enhancing winter and spring streamflow. These investigators did not include physiological feedback responses from increased $\mathrm{CO}_{2}$; plant response may well have tempered the extremity of their con- clusions. Nevertheless, a shift in the timing of spring snowmelt will influence water storage capabilities in the Rocky Mountains and water distribution facilities to agriculture and municipalities.

There are important biogeochemical implications of a snowpack that does not retain its solutes until spring melt. Currently, Rocky Mountain streams experience a spring pulse of nitrate and other solutes that are retained in the snowpack and soils until melt, resulting in very high stream nitrate concentrations [Campbell et al., 1995; Williams et al., 1996a, b]. The spring pulse of nutrients and pollutants will be replaced by a more gradual leakage of chemicals into soils with a dynamic snowpack that melts through the winter. Because a gradual release of $\mathrm{N}$ increases the possibility that nitrate will be actively taken up and retained by soil microbes, organic matter, and plants, stream nitrate concentrations may actually decrease under a warming scenario [Cadle et al., 1987; Magill et al., 1997]. A climate warming scenario may thus relieve some of the current ecological pressure brought about by excess $\mathbf{N}$ deposition [Fenn et al., 1998; Baron and Campbell, 1997].

Cooler and slightly wetter scenarios are more similar to observed climate and hydrologic responses over the past 20-40 years [Stohlgren et al., 1998; Williams et al., 1996a]. They suggest more persistent snowpacks, longer snowmelt-driven runoff, and decreased plant productivity at these high elevations. Atmospheric feedbacks can reinforce cooler climate, as the albedo from persistent snowcover reflects shortwave radiation [Barry, 1990]. A cooler mountain climate will result in lower rates of photosynthesis and thus transpiration. While this translates to a shorter season for summer recreation at high elevations, it may yield greater year-long and seasonal water availability for downstream users.

Recent GCM scenarios suggest slight changes in western United States temperatures but increases in winter precipitation amounts (Hadley Centre, 1998). Our model results suggest high-elevation Rocky Mountain basins will respond with increased water yield, and this will mostly be due to enhanced snowmelt runoff or strictly physical hydrologic processes. Vegetation processes in these high unproductive ecosystems have little influence on water retention and loss.

To summarize, model results suggest alpine tundra productivity is currently water limited and will increase somewhat with increased precipitation. Forest vegetation productivity increases with increased temperatures and increased $\mathrm{CO}_{2}$ availability. A long-term implication of this is upslope movement of forest vegetation. However, it does not appear that climate or $\mathrm{CO}_{2}$ influences on vegetation have much of an effect on vaporization or discharge. Vegetation cover in headwater basins like Loch Vale is minimal, so there is greater response of hydrologic processes to purely physical changes in climate than to those mediated by vegetation. When all water fluxes that influence hydrologic runoff are included, total discharge is relatively insensitive to temperature but is very responsive to changes in precipitation. The amount of discharge was not responsive to temperature, but the timing certainly was, varying by up to 6 weeks with warming. While the snowpack became greater or less with $2^{\circ} \mathrm{C}$ cooling or warming, its pattern was the same as with current climate, differing only in magnitude and in timing of melt. A fundamental change occurred with $4^{\circ} \mathrm{C}$ warming, suggesting a threshold was crossed that allowed snowmelt to occur through much of the winter. This causes moisture from snow to seep into soils, and will alter current biogeochemical processing of solutes in soils and influence the passage of nitrogen from soils into stream waters. 
The warming with increased winter precipitation, as suggested by the Hadley Centre and other GCM outputs, may have less of an influence on Rocky Mountain hydrologic processes than early predictions suggested. The urban and agricultural demand for water from mountain runoff almost certainly will increase with warming, but our model suggests the supply, at least at these highest elevations, will remain similar to past conditions. The biggest change appears to be in the timing of snowmelt and discharge, and this may cause regional water managers to evaluate water storage and distribution capabilities. A similar response was projected for California rivers by Lettenmaier and Gan [1990] and by Rango [1995] for rivers in Colorado, California, and British Columbia. Our simulations and theirs suggest that summer flows will be lower, a situation that could lead to changes in riverine habitats and water quality for fish, invertebrates, and algae. The convergence of several completely different simulations of mountain hydrologic responses to climate would lend strength to our message that water and natural resource managers take note that changes in climate will influence the timing of water resources from the mountains through the southern Rocky Mountains and possibly other western mountains as well.

Acknowledgments. This research was supported by USGS grant COLR-R92-0201, 140, NOAA contract NA36GP0378, and the USGS Watershed Studies Program. This is a contribution of the Colorado Rockies Global Change Project.

\section{References}

Baker, W. L., and P. J. Weisberg, Landscape analysis of the foresttundra ecotone in Rocky Mountain National Park, Colorado, Prof. Geogr., 47, 361-375, 1995.

Band, L. E., Effect of land surface representation on forest water and carbon budgets, J. Hydrol., 150, 749-772, 1993.

Band, L. E., P. Patterson, R. Nemani, and S. W. Running, Forest ecosystem processes at the watershed scale: Incorporating hillslope hydrology, Agric. For. Meteorol., 63, 93-126, 1993.

Band, L. E., D. S. MacKay, I. F. Creed, R. Semkin, and D. Jeffries, Ecosystem processes at the watershed scale: Sensitivity to potential climate change, Limnol. Oceanogr., 41, 928-938, 1996.

Baron, J. S. (Ed.), Biogeochemistry of a Subalpine Ecosystem: Loch Vale Watershed, Ecol. Stud., vol. 90, Springer-Verlag, New York, 1992.

Baron, J., and O. P. Bricker, Hydrologic and chemical flux in Loch Vale watershed, Rocky Mountain National Park, in Chemical Quality of Water and the Hydrologic Cycle, edited by R. C. Averett and D. M. McKnight, pp. 141-157, A. F. Lewis, New York, 1987.

Baron, J. S., and D. H. Campbell, Nitrogen fluxes in a high elevation Colorado Rocky Mountain basin, Hydrol. Processes, 11, 783-799, 1997.

Baron, J., and A. S. Denning, Hydrologic budget estimates, in Biogeochemistry of a Subalpine Ecosystem: Loch Vale Watershed, Ecol. Stud., vol. 90, edited by J. Baron, pp. 28-47 Springer-Verlag, New York, 1992.

Baron, J. S., M. D. Hartman, T.G.F. Kittel, D. S. Ojima, L. E. Band, and R. L. Lammers, The influence of land cover, water redistribution, and temperature on ecosystem processes in the South Platte basin, Ecol. Appl., 8, 1037-1051, 1998.

Barry, R. G., A climatological transect of the east slope of the Front Range, Colorado, Arct. Alp. Res., 5, 89-110, 1973.

Barry, R. G., Changes in mountain climate and glacio-hydrological responses, Mt. Res. Dev., 10, 61-170, 1990.

Barry, R. G., Past and potential future changes in mountain environments: A review, in Mountain Environments in Changing Climates, edited by M. Beniston, pp. 3-33, Routledge, New York, 1994.

Beven, K. J., and M. J. Kirkby, A physically-based, variable contributing area model of basin hydrology, Hydrol. Sci. Bull., 24, 43-69, 1979.

Cadle, S. H., J. M. Dasch, and R. V. Kopple, Composition of snowmelt and runoff in northern Michigan, Environ. Sci. Technol., 21, 295299,1987
Cairns, D. M., Development of a physiologically mechanistic model for use at the alpine treeline ecotone, Phys. Geogr., 15, 104-124, 1994. Campbell, D. H., D. W. Clow, G. P. Ingersoll, M. A. Mast, N. E. Spahr, and J. T. Turk, Processes controlling the chemistry of two snowmeltdominated streams in the Rocky Mountains, Water Resour. Res., 31, 2811-2821, 1995.

Chase, T. N., R. A. Pielke, T.G.F. Kittel, and J. Baron, Potential impacts on Rocky Mountain weather due to land use changes on the adjacent Great Plains, J. Geophys. Res., 104, 673-690, 1999.

Cline, D. W., Snow surface energy exchanges and snowmelt at a continental, midlatitude alpine site, Water Resour. Res., 33, 689-701, 1997.

Copeland, J. H., R. A. Pielke, and T.G.F. Kittel, Potential climatic impacts of vegetation change: A regional modeling study, J. Geophys. Res., 101, 7409-7418, 1996.

Cotton, W. R., and R. A. Pielke, Human Impacts on Weather and Climate, Geophys. Sci. Ser., vol. 2, Cambridge Univ. Press, New York, 1995.

Creed, I. F., L. E. Band, N. W. Foster, I. K. Morrison, J. A. Nicolson, R. S. Semkin, and D. S. Jeffries, Regulation of nitrate-N release from temperate forests: A test of the N flushing hypothesis, Water Resour. Res., 32, 3337-3354, 1996.

Cure, J. D., and B. Acock, Crop response to carbon dioxide doubling: A literature survey, Agric. For. Meteorol., 38, 127-145, 1986.

Denning, A. S., J. Baron, M. A. Mast, and M. A. Arthur, Hydrologic pathways and chemical composition of runoff during snowmelt in Loch Vale watershed, Rocky Mountain National Park, Colorado USA, Water Air Soil Pollut., 59, 107-123, 1991.

Dracup, J. A., and D. R. Kendall, Floods and droughts, in Climate Change and US Water Resources, edited by P. E. Waggoner, pp. 243-267, John Wiley, New York, 1990.

Eisel, L., and J. D. Aiken, Platte River basin study, report, 68 pp., West. Water Policy Rev. Adv. Comm., Denver, Colo., 1997.

Fenn, M. E., M. A. Poth, J. D. Aber, J. S. Baron, B. T. Bormann, D. W. Johnson, A. D. Lemly, S. G. McNulty, D. F. Ryan, and R. Stottlemyer, Nitrogen excess in North American ecosystems: Predisposing factors, ecosystem responses, and management strategies, Ecol. Appl., 8, 706-733, 1998.

Giorgi, F., C. S. Brodeur, and G. T. Bates, Regional climate change scenarios over the United States produced with a nested regional climate model, J. Clim., 7, 375-399, 1994.

Grassl, H., The Alps under local, regional, and global pressure, in Mountain Environments in Changing Climates, edited by M. Beniston, pp. 34-41, Routledge, New York, 1994.

Graumlich, L. J., Long-term vegetation change in mountain environments: paleoecological insights into modern vegetation dynamics, in Mountain Environments in Changing Climates, edited by M. Beniston, pp. 167-179, Routledge, New York, 1994.

Hansen, J. E., M. Sato, R. Ruedy, A. Lacis, and J. Glascoe, Global climate data and models: A reconciliation, Science, 281, 930-932, 1998.

Hartman, M. D., J. S. Baron, R. B. Lammers, D. W. Cline, L. E. Band, G. E. Liston, and C. Tague, Simulations of snow distribution and hydrology in a mountain basin, Water Resour. Res., 35, 1587-1603, 1999.

Holling, C. S., Surprise for science, resilience for ecosystems, and incentives for people, Ecol. Appl., 6, 733-735, 1996.

Hunt, E. R., Jr., S. C. Piper, R. Nemani, C. D. Keeling, R. D. Otto, and S. W. Running, Global net carbon exchange and intra-annual atmospheric $\mathrm{CO}_{2}$ concentrations predicted by an ecosystem process model and three-dimensional atmospheric transport model, Global Biogeochem. Cycles, 10, 431-456, 1996.

Lammers, R. B., Extending hydro-ecological simulation models from local to regional scales, Ph.D. dissertation, Univ. of Toronto, Toronto, Ont., Canada, 1998.

Lammers, R. B., L. E. Band, and C. L. Tague, Scaling behaviour of watershed processes, in Scaling-up, edited by P. van Gardingen, G. Foody, and P. Curran, pp. 295-317, Cambridge Univ. Press, New York, 1997.

Lettenmaier, D. P., and T. Y. Gan, Hydrologic sensitivities of the Sacramento-San Joaquin River basin, California, to global warming, Water Resour. Res., 26, 69-86, 1990.

Lohammer, T., S. Larsson, S. Linder, and S. Falk, FAST-Simulation models of gaseous exchange in Scots pine, Ecol. Bull., 32, 505-523, 1980.

Magill, A. H., J. D. Aber, J. J. Hendricks, R. D. Bowden, J. M. Melillo, 
and P. A. Steudler, Biogeochemical response of forested ecosystems to simulated chronic nitrogen deposition, Ecol. Appl., 7, 402-415, 1997.

Melack, J. M., J. Dozier, C. R. Goldman, D. Greenland, A. M. Milner, and R. J. Naiman, Effects of climate change on inland waters of the Pacific Coastal Mountains and Western Great Basin of North America, Hydrol. Processes, 11, 153-174, 1997.

Monteith, J. L., Evaporation and environment, in Proceedings 19th Symposium Society for Experimental Biology, pp. 205-233, Soc. for Exp. Biol., Lancaster, England, 1965.

Nash, L. L., and P. H. Gleick, The sensitivity of streamflow in the Colorado Basin to climatic changes, J. Hydrol., 125, 221-241, 1991.

Peet, R. K., Forests of the Rocky Mountains, in North American Terrestrial Vegetation, edited by M. G. Barbour and W. D. Billings, pp. 64-101, Cambridge Univ. Press, New York, 1989.

Pielke, R. A., Sr., T. J. Lee, T.G.F. Kittel, T. N. Chase, J. M. Cram, and J. S. Baron, Effects of mesoscale vegetation distributions in mountainous terrain on local climate, in Mountain Environments in Chang ing Climates, edited by M. Beniston, pp. 121-135, Routledge, New York, 1994.

Rango, A., Effects of climate change on water supplies in mountainous snowmelt regions, World Resour. Rev., 7, 315-325, 1995.

Rango, A., and V. F. van Katwijk, Climate change effects on the snowmelt hydrology of western North American mountain basins, IEEE Trans. Geosci. Remote Sens., 28, 970-975, 1990.

Reasoner, M. A., The late Quaternary alpine and subalpine lacustrine records: Canadian and Colorado Rocky Mountains, Ph.D. dissertation, Univ. of Alberta, Edmonton, Alberta, Canada, 1996.

Revelle, R. R., and P. E. Waggoner, Effects of carbon dioxide-induced climatic change on water supplies in the western United States, in Changing Climate, pp. 252-261, Natl. Acad. Press, Washington, D. C., 1983.

Running, S. W., and J. C. Coughlan, A general model of forest ecosystem processes for regional applications, I, Hydrologic balance, canopy gas exchange, and primary production processes, Ecol. Modell., 42, 125-154, 1988.

Running, S. W., and R. Nemani, Regional hydrologic and carbon balance responses of forests resulting from potential climate change, Clim. Change, 19, 349-368, 1991.

Running, S. W., R. Nemani, and R. D. Hungerford, Extrapolation of synoptic meteorological data in mountainous terrain, and its use for simulating forest evapotranspiration and photosynthesis, Can.J. For Res., 17, 472-483, 1987.

Running, S. W., R. Nemani, D. L. Peterson, L. E. Band, D. F. Potts, L. L. Pierce, and M. A. Spanner, Mapping regional forest evapo- transpiration and photosynthesis by coupling satellite data with ecosystem simulation, Ecology, 70, 1090-1101, 1989.

Schlesinger, W. H., Biogeochemistry: An Analysis of Global Change, 2nd ed., Academic, San Diego, Calif., 1997.

Sierra Business Council, Sierra Nevada wealth index: Understanding and tracking our region's wealth, report, 48 pp., Truckee, Calif., 1996.

Sims, P. L., Grasslands, in North American Terrestrial Vegetation, edited by M. G. Barbour and W. D. Billings, pp. 265-286, Cambridge Univ. Press, New York, 1989.

Stohlgren, T. S., T. N. Chase, R. A. Pielke, T.G.F. Kittel, and J. S. Baron, Evidence that local land use practices influence regional climate and vegetation patterns in adjacent natural areas, Global Change Biol., 4, 495-504, 1998.

van Katwijk, V. F., A. Rango, and A. E. Childress, Effect of simulated climate change on snowmelt runoff in selected basins, Water Resour. Bull., 29, 755-766, 1993.

Walker, M. D., P. J. Webber, E. H. Arnold, and D. Ebert-May, Effects of interannual climate variation on aboveground phytomass in alpine vegetation, Ecology, 75, 393-408, 1994.

Watson, R. T., M. C. Zinyowara, and R. H. Moss (Eds.), Climate Change: Second Assessment Report of the Intergovernmental Panel on Climate Change, Cambridge Univ. Press, New York, 1996.

Webber, P. J., and D. E. May, The magnitude and distribution of belowground plant structures in the alpine tundra of Niwot Ridge, Colorado, Arct. Alp. Res., 9, 157-174, 1977.

Williams, M. W., M. Losleben, N. Caine, and D. Greenland, Changes in climate and hydrochemical responses in a high-elevation catchment in the Rocky Mountains, USA, Limnol. Oceanogr., 41, 939946, 1996a.

Williams, M. W., J. S. Baron, N. Caine, R. Sommerfeld, and R. A. Sanford, Nitrogen saturation in the Rocky Mountains, Environ. Sci. Technol., 30, 640-646, 1996b.

L. E. Band, Department of Geography, University of North Carolina, Chapel Hill, NC 27599. (Iband@email.unc.edu)

J. S. Baron and M. D. Hartman, Natural Resource Ecology Laboratory, Colorado State University, Fort Collins, CO 80523. (jill@nrel.colostate.edu; melannie@nrel.colostate.edu)

R. B. Lammers, Complex Systems Research Center, University of New Hampshire, Durham, NH 03824. (lammers@cdac.sr.unh.edu)

(Received March 10, 1999; revised August 19, 1999; accepted August 27, 1999.) 